\title{
ORAl1 wt Allele
}

National Cancer Institute

\section{Source}

National Cancer Institute. ORAl1 wt Allele. NCI Thesaurus. Code C88518.

Human ORAI1 wild-type allele is located in the vicinity of $12 \mathrm{q} 24.31$ and is approximately $15 \mathrm{~kb}$ in length. This allele, which encodes calcium release-activated calcium channel protein 1 , is involved in the modulation of both $\mathrm{T}$-cell pathogen response and calcium influx. Mutation of the gene is associated with congenital severe combined immunodeficiency. 